\title{
Real-Time PCR Assays for the Quantification of Phialophora gregata f. sp. sojae IGS Genotypes A and B
}

\author{
T. J. Hughes, Z. K. Atallah, and C. R. Grau
}

First and third authors: Department of Plant Pathology, University of Wisconsin-Madison, 1630 Linden Dr., Madison 53706; and second author: Department of Plant Pathology, University of California, 1636 East Alisal St., Salinas 93905. Accepted for publication 18 May 2009.

\section{ABSTRACT}

Hughes, T. J., Atallah, Z. K., and Grau, C. R. 2009. Real-time PCR assays for the quantification of Phialophora gregata f. sp. sojae IGS genotypes A and B. Phytopathology 99:1008-1014.

Populations of Phialophora gregata f. sp. sojae, the causal agent of brown stem rot (BSR) of soybean, consist of two genotypes, designated A and $\mathrm{B}$. These genotypes are differentiated by an insertion or deletion in the intergenic spacer region (IGS) of ribosomal DNA. The two genotypes differ in the type and severity of symptoms they cause and have displayed preferential host colonization. Methods to quantify populations of $P$. gregata f. sp. sojae and to distinguish between the two genotypes are essential to understanding this host-pathogen interaction and to improv- ing control of BSR. A real-time, quantitative polymerase chain reaction (qPCR) assay was developed for the specific detection and quantification of $P$. gregata f. sp. sojae genotype A. This assay is specific to $P$. gregata $\mathrm{f}$. sp. sojae genotype A, sensitive to $50 \mathrm{fg}$ of DNA, and unaffected by the presence of soybean or soil DNA. When the $P$. gregata f. sp. sojae genotype A-specific primer/probe set is used in a multiplex qPCR assay with a previously developed primer/probe set which indiscriminately amplifies both genotypes, the quantity of $P$. gregata $\mathrm{f}$. sp. sojae genotype $\mathrm{B}$ can be indirectly determined. This multiplex assay provides a rapid and robust method for studying both the population size and genetic structure of $P$. gregata f. sp. sojae in its soybean host and in the soil.
Populations of the soilborne fungal pathogen Phialophora gregata f. sp. sojae (syn. Cephalosporium gregataum and Cadophora gregata), the cause of brown stem rot (BSR) of soybean (Glycine $\max ($ L.) Merr.), consist of two genotypes, A and B, which are distinguished by a 188-bp insertion/deletion (INDEL) in the intergenic spacer region (IGS) of the ribosomal DNA (3). The two genotypes are found throughout the north-central United States and are capable of cohabiting the same field and the same plant $(3,9,11)$. Genotypic differences among isolates of $P$. gregata f. sp. sojae correspond to differences in the type and severity of symptoms produced. In general, isolates of $P$. gregata $\mathrm{f}$. sp. sojae genotype A are considered more aggressive, causing more severe BSR foliar and stem symptoms than isolates of $P$. gregata f. sp. sojae genotype B $(4,6)$. Studies conducted by Chen et al. (3), Malvick et al. (9), and Meng et al. (11) also indicate that genotypes A and B display cultivar preference. Soybean cultivars susceptible to BSR are preferentially colonized by isolates of genotype A while cultivars resistant to BSR are preferentially colonized by isolates of genotype B. This preferential colonization is further influenced by the source of resistance to BSR $(3,9)$. The ratio of isolates of $P$. gregata $\mathrm{f}$. sp. sojae genotype A to genotype $\mathrm{B}$ is greater $(\approx 1: 9)$ for BSR-resistant cultivars derived from plant introduction (PI) $88788(7,13)$ than for BSR-resistant cultivars containing one or more $R b s$ genes $(\approx 1: 2)(3,9)$.

Essential to a better understanding of this host-pathogen system and long-term control of BSR is the ability to quantify populations of $P$. gregata $\mathrm{f}$. sp. sojae and to distinguish between genotypes A and B. Currently, identification of genotypes A and B is limited to polymerase chain reaction (PCR) amplification of the IGS region followed by gel electrophoresis (3). This method does not allow for quantification. Until recently, quantification of $P$.

Corresponding author: T. J. Hughes; E-mail address: tjh@plantpath.wisc.edu

doi:10.1094/PHYTO-99-9-1008

(C) 2009 The American Phytopathological Society gregata f. sp. sojae was determined by dilution plating finely ground stem material onto a semiselective medium $(1,8,12)$. This method is labor intensive, lacks sensitivity to low levels of colonization, and does not distinguish between genotypes A and B. In 2007, Malvick and Impullitti (10) used the specificity and sensitivity of fluorescence-based PCR and developed a quantitative, real-time PCR (qPCR) assay to quantify P. gregata f. sp. sojae in plant tissue and in soil. Although this qPCR assay is rapid, sensitive, and selective, it does not distinguish between genotypes A and B of P. gregata f. sp. sojae.

Real-time PCR assays combine the exponential amplification of PCR with the specificity of DNA hybridization assays while reducing time, labor, and overall cost. For each amplicon of interest, an individual set of primers and a sequence-specific, fluorescently labeled probe are developed. By using different color fluorophores, different amplicons can be detected in one multiplex reaction, further minimizing time and expense. For genotypes A and B, the DNA sequence from the IGS region could be utilized to design two primer and probe sets, which would allow for the specific quantification and differentiation of each genotype in a single reaction. Unfortunately, the IGS sequences of $P$. gregata $\mathrm{f}$. sp. sojae genotypes $\mathrm{A}$ and $\mathrm{B}$ are identical to one another, with the exception of the 188-bp INDEL in the IGS sequence of genotype A (3). Within the 188-bp INDEL of genotype A, a sequence was identified to be specific to isolates of genotype A (T. J. Hughes, unpublished data). A method of quantification of genotype B is proposed which uses the specific quantification of genotype A and the qPCR assay of Malvick and Impullitti (10). The quantification of genotype B would be determined from the difference between the total quantity of DNA detected of $P$. gregata f. sp. sojae and the quantity of $P$. gregata $\mathrm{f}$. sp. sojae genotype A.

The objectives of this study were to (i) develop a qPCR assay for the specific detection of $P$. gregata $\mathrm{f}$. sp. sojae genotype A in laboratory cultures, plant tissues, and soil; (ii) develop a multiplex qPCR assay using P. gregata f. sp. sojae general primers and 
probe (10) with $P$. gregata f. sp. sojae genotype A-specific primers and probe; and (iii) determine the validity of taking the quantity of total DNA detected of $P$. gregata $\mathrm{f}$. sp. sojae and subtracting the quantity of $P$. gregata $\mathrm{f}$. sp. sojae genotype A to obtain an estimate of the quantity of $P$. gregata f. sp. sojae genotype B.

\section{MATERIALS AND METHODS}

DNA isolation from pure culture, plant, and soil samples. An array of fungi, oomycetes, and bacteria were selected to determine whether cross-amplification occurred with the primer/ probe set developed for P. gregata f. sp. sojae genotype A (Table 1). Total genomic DNA was obtained from each organism by using the FastDNA Spin Kit (MP Biomedicals, LLC, Solon, OH) following the manufacture's protocol unless DNA was provided in lieu of an isolate (Table 1). Soil was collected from the West Madison Agricultural Experiment Station, Verona, WI in an area with no known history of soybean production. In total, 10 soil cores, $2.54 \mathrm{~cm}$ in diameter and 13 to $15 \mathrm{~cm}$ long, were obtained from a grass alleyway adjacent to a stand of poplar trees (Populus spp.). Cores were combined and thoroughly mixed. A 400-g subsample of soil was infested with $50 \mathrm{ml}$ of a suspension of three isolates of genotype A at $1 \times 10^{7}$ conidia and mycelia per $\mathrm{ml}$
(6) (Table 1). Infested and noninfested soil was air dried and pulverized with a rubber mallet. DNA was extracted from $1 \mathrm{~g}$ of pulverized soil sample by using the MoBio (Carlsbad, CA) UltraClean Soil DNA extraction kit and the MoBio Vortex Adaptor tube holder according to manufacturer's protocol for maximum yield of DNA. PCR inhibitors were removed during extraction by using the inhibitor removal solution (IRS) provided with the kit.

Seed of BSR-susceptible soybean cv. Corsoy 79 and BSRresistant PI 567.157A were germinated in medium-grade vermiculite in 25.4-by-50.8-cm, 96-well flats containing commercial grade Bradyrhizobium japonicum (Nitragin Inoculants; Liphatech Inc., Milwaukee, WI) for nodulation. Seedlings were inoculated at the VC-V1 growth stage (cotyledons fully expanded) with a suspension of an isolate of $P$. gregata $\mathrm{f}$. sp. sojae genotype A or genotype $\mathrm{B}$ at $1 \times 10^{6}$ conidia and mycelia per $\mathrm{ml}$ with a modified root dip method (6). Negative control plants were mock inoculated by the same method with sterilized green bean broth. Plants were grown for $\approx 6$ to 7 weeks until the R2-R3 growth stage (full flowering-early pod development). Plants were cut at the soil level, thoroughly washed to remove residual dirt, and air dried. Soybean stems were ground in liquid nitrogen and DNA was extracted from $100 \mathrm{mg}$ of ground tissue with the FastDNA Spin Kit according to the manufacturer's protocol with the following

TABLE 1. Fungi, oomycetes, and bacteria used to test specificity of Phialophora gregata f. sp. sojae genotype A-specific primers and TaqMan probe

\begin{tabular}{|c|c|c|c|c|}
\hline \multirow[b]{2}{*}{ Organism name } & \multirow[b]{2}{*}{ Isolate ID } & \multicolumn{3}{|c|}{ Origin of isolate } \\
\hline & & Supplier ${ }^{\mathrm{x}}$ & State, country & Crop \\
\hline Acremonium spp. & Acr 4-3 & C. Grau & Wisconsin & Soybean \\
\hline Acremonium spp. & Acr 4-4 & C. Grau & Wisconsin & Soybean \\
\hline A. dichromosporum & 32181 & ATCC & W. Australia & Wheat \\
\hline Alternaria alternata ${ }^{\mathrm{y}}$ & $\ldots$ & P. Rogers & Wisconsin & Carrot \\
\hline Bradyrhizobium japonicum & USDA110 & J.-M. Ané & Florida & Soybean \\
\hline Colletotrichum trifolli & 2SP2 & D. Sharpee & Wisconsin & Alfalfa \\
\hline Diaporthe phaseolorum var. sojae & DPS & C. Grau & Wisconsin & Soybean \\
\hline D. phaseolorum var. sojae & $233-17$ & C. Grau & Wisconsin & Soybean \\
\hline D. phaseolorum var. caulivora & DPC & C. Grau & Wisconsin & Soybean \\
\hline D. phaseolorum var. caulivora & DPC9 & C. Grau & Wisconsin & Soybean \\
\hline D. phaseolorum var. meridionalis & DPM & C. Grau & Wisconsin & Soybean \\
\hline Fusarium spp. & $\ldots$ & C. Grau & Wisconsin & Soybean \\
\hline F. virguliforme $\mathrm{e}^{\mathrm{y}}$ & $\ldots$ & S. Giammaria & Arkansas & Soybean \\
\hline Gaeumannomyces graminis var. avenae & $\ldots$ & G. Jung & Wisconsin & Turf \\
\hline Gliocladium spp. & $\ldots$ & T. Hughes & Wisconsin & Soybean \\
\hline Phialophora gregata f. sp. sojae genotype A & Fulton $\mathrm{OH}$ & W. Chen & Ohio & Soybean \\
\hline P. gregata f. sp. sojae genotype A & IN6 & W. Chen & Indiana & Soybean \\
\hline P. gregata f. sp. sojae genotype A & F5-3 & W. Chen & Illinois & Soybean \\
\hline P. gregata f. sp. sojae genotype B & $\mathrm{C} 2-2-2$ & W. Chen & Wisconsin & Soybean \\
\hline P. gregata f. sp. sojae genotype B & S5-5 & W. Chen & Illinois & Soybean \\
\hline P. gregata f. sp. sojae genotype B & F3-8 & W. Chen & Illinois & Soybean \\
\hline Hymenula cerealis & $\ldots$ & T. Murray & Washington & Wheat \\
\hline Macrophomina phaseolina & TN3 & A. Mengistu & Tennessee & Soybean \\
\hline Phoma medicaginis & $\ldots$ & C. Grau & Wisconsin & Alfalfa \\
\hline Phytophthora medicaginis & $25-1$ & C. Grau & Wisconsin & Alfalfa \\
\hline P. sojae & $\ldots$ & Z. Atallah & Wisconsin & Soybean \\
\hline Plectosporium tabacinum & $\mathrm{Pt} 2$ & C. Grau & Wisconsin & Soybean \\
\hline Pythium spp. & $\ldots$ & C. Grau & Wisconsin & Soybean \\
\hline P. ultimum & $\ldots$ & C. Grau & Wisconsin & $\ldots$ \\
\hline Rhizoctonia solani & $\ldots$ & W. Stevenson & Wisconsin & Potato \\
\hline R. solani & BT4B & C. Grau & Wisconsin & Alfalfa \\
\hline Sclerotinia sclerotiorum & $\ldots$ & C. Grau & Wisconsin & Soybean \\
\hline Verticillium dahliae ${ }^{\mathrm{y}}$ & $\ldots$ & Z. Atallah & Wisconsin & Potato \\
\hline Unknown ${ }^{\mathrm{Z}}$ & $165 \mathrm{~V} 2$ & C. Grau & Wisconsin & Soybean \\
\hline Unknown & Black phenotype & T. Hughes & Wisconsin & Soybean \\
\hline Unknown & Red phenotype & T. Hughes & Wisconsin & Soybean \\
\hline
\end{tabular}

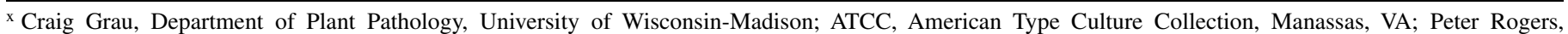
Nunhems USD, Oregon; Jean-Michael Ané, Department of Agronomy, University of Wisconsin-Madison; Debra Sharpee, Pioneer Hi-Bred International, Wisconsin; Silvina Giammaria, Agroindustial Obispo Colombres, Argentina; Geunhwa Jung, Plant-Soil-Insect Science Department, University of Massachusetts; Weidong Chen, United States Department of Agriculture-Agricultural Research Service (USDA-ARS), Pullman, WA; Timothy Murray, Department of Plant Pathology, Washington State University; Alemu Mengistu, USDA-ARS, Jackson, TN; Zahi Kanaan-Atallah, Department of Plant Pathology, University of California; Teresa Hughes, Department of Plant Pathology, University of Wisconsin-Madison.

y DNA of isolate was supplied in lieu of the isolate itself.

${ }^{\mathrm{z}}$ Fungus commonly isolated from field-grown soybean stems. 
modification. For the initial buffer solution, each tube received $400 \mu \mathrm{l}$ of CLS-Y buffer, $400 \mu \mathrm{l}$ of CLF-VF buffer, and $200 \mu \mathrm{l}$ of PPS solution (buffers and solutions provided with the kit). Following extraction, DNA was further purified to remove inhibitors by using AMPure magnetic beads (Agencourt Bioscience Corp., Beverly, MA) according to the manufacturer's protocol. For soybean DNA free of P. gregata f. sp. sojae, DNA was extracted from 7- to 14-day-old, noninoculated seedlings of Corsoy 79. DNA from all samples was quantified with the NanoDrop ND-1000 spectrophotometer (Thermofisher Scientific, Wilmington, DE) and the concentration of DNA adjusted to $1 \mathrm{ng} / \mu \mathrm{l}$ for soil samples or $4 \mathrm{ng} / \mu \mathrm{l}$ for plant samples with nuclease-free, diethylpyrocarbonate-treated water (Fisher Scientific, Pittsburg).

$\boldsymbol{P}$. gregata f. sp. sojae genotype A-specific primers and probe. Oligonucleotide primers and TaqMan probe were developed from the 3' end (base pairs 586-654) of the INDEL sequence located within the IGS sequence of $P$. gregata $\mathrm{f}$. sp. sojae genotype A (GenBank accession no. AF249311) (3). Sequences for forward and reverse primers and probe were: PgsAspF (forward primer) 5'-GGA ATT GGT GGG AGA GG-3'; PgsAspR (reverse primer) 5'-GAC TTC TAG GGT ATG TCT ACA GTG-3'; and PgsAspPR (probe) 5'-AGG CTA CTC TTA CAG GCT CTC$3^{\prime}$. The 5' terminus of PgsAspPR was labeled with the fluorophore dye CAL Fluor Red 610 and the $3^{\prime}$ terminus was labeled with the black hole quencher BHQ-2. PgsAspPR was synthesized by Biosearch Technologies (Novato, CA). Primers PgsAspF and PgsAspR, which amplified a 69-bp fragment, were synthesized by Applied Biosystems (Foster City, CA).

Sensitivity and specificity of primers and probe. Sequences for the $P$. gregata f. sp. sojae genotype A-specific primer/probe set and the 69-bp amplicon were compared with all sequences in the National Center for Biotechnology Information (NCBI) database (www.ncbi.nlm.nih.gov/) to identify homologous sequences by performing nucleotide-nucleotide BLAST searches. Primer and probe specificity was tested against 5 to $50 \mathrm{ng}$ of DNA from 36 isolates of fungi, oomycetes, and bacteria commonly associated with soybean or related to Phialophora spp. (Table 1). Sensitivity and specificity of the genotype A-specific primer/ probe set was determined by using serially diluted DNA from three isolates of genotype A and three isolates of genotype B (Table 1). To determine the effect of soybean and soil DNA on qPCR detection and amplification of genotype A DNA (potential inhibition of PCR amplification), $10 \mathrm{ng}$ of DNA extracted from a noninoculated soybean plant or $1 \mathrm{ng}$ of DNA extracted from noninfested soil was added to serial dilutions of DNA from genotype A.

Each qPCR reaction consisted of $5 \mu \mathrm{l}$ of template DNA, $900 \mathrm{nM}$ PgsAspF and PgsAspR, 200 nM PgsAspPR, and 1× iQ Supermix
(Bio-Rad, Hercules, CA) in $25 \mu$ of total volume. Cycling parameters were $50^{\circ} \mathrm{C}$ for $2 \mathrm{~min}$ and $95^{\circ} \mathrm{C}$ for $10 \mathrm{~min}$, followed by 40 cycles of $95^{\circ} \mathrm{C}$ for $15 \mathrm{~s}$ and $60^{\circ} \mathrm{C}$ for $1 \mathrm{~min}$. All reactions were run in a Bio-Rad iCycler iQ multicolor real-time PCR detection system in either duplicate or triplicate. Each set of reactions included DNA extracted from an isolate of genotype A and an isolate of genotype B (Table 1) and a negative control (no DNA template). The quantity of $P$. gregata f. sp. sojae genotype A DNA present in each sample was determined by absolute quantification based on a standard curve. Standard curves were developed from DNA extracted from pure culture isolates of $P$. gregata f. sp. sojae genotype A (Table 1). Standards were in either duplicate or triplicate in each set of reactions.

Multiplex assay. The primer and probe set BSRqPCRf1BSRqPCRr1-BSRqPCRpb1 (10) (P. gregata f. sp. sojae general primer/probe set) was previously designed based on the 1,020-bp IGS sequence of $P$. gregata $\mathrm{f}$. sp. sojae and is used to amplify DNA of both genotypes. The $5^{\prime}$ terminus of BSRqPCRpb1 was labeled with the fluorophore dye 6-FAM. Because BSRqPCRpb1 is a minor groove-binding probe, the $3^{\prime}$ terminus was labeled with the nonfluorescent quencher MGBNFQ. Both primers and probe were synthesized by Applied Biosystems.

Each multiplex qPCR reaction consisted of $5 \mu$ of template DNA, $450 \mathrm{nM}$ BSRqPCRf1 and BSRqPCRr1, $300 \mathrm{nM}$ PgsAspF and PgsAspR, $100 \mathrm{nM}$ BSRqPCRpb1, $125 \mathrm{nM}$ PgsAspPR, and 1× iQ Supermix (Bio-Rad) in $25 \mu \mathrm{l}$ of total volume. All reactions were run in a Bio-Rad iCycler iQ multicolor real-time PCR detection system in either duplicate or triplicate, as previously described. The total quantity of $P$. gregata $\mathrm{f}$. sp. sojae and the quantity of $P$. gregata $\mathrm{f}$. sp. sojae genotype A DNA present in each sample was determined by absolute quantification based on a standard curve.

Quantification of P. gregata f. sp. sojae genotype B. To determine whether DNA of $P$. gregata f. sp. sojae genotype B could be quantified using the above multiplex qPCR assay, six combinations of genotypes A and B were prepared with a total DNA concentration of $5 \mathrm{ng}$ (Table 2). The quantity of genotype B was determined by subtracting the quantity of genotype A DNA detected from the quantity of $P$. gregata $\mathrm{f}$. sp. sojae DNA ("Total" DNA) detected with the general primer/probe set in multiplex qPCR.

Quantification of $P$. gregata f. sp. sojae genotypes A and B from naturally infested soil and field-grown plants. Soil cores and soybean stems were collected from a field located at the Arlington Agricultural Research Station, Arlington, WI, with a history of BSR. Soil cores were collected in June from four locations where BSR-resistant cv. Jack was grown in monoculture and four locations where BSR-susceptible cv. Corsoy 79 was

TABLE 2. Quantity of DNA of Phialophora gregata f. sp. sojae genotypes A and B added per reaction and the quantity determined with a multiplex quantitative, real-time polymerase chain reaction (qPCR) assay

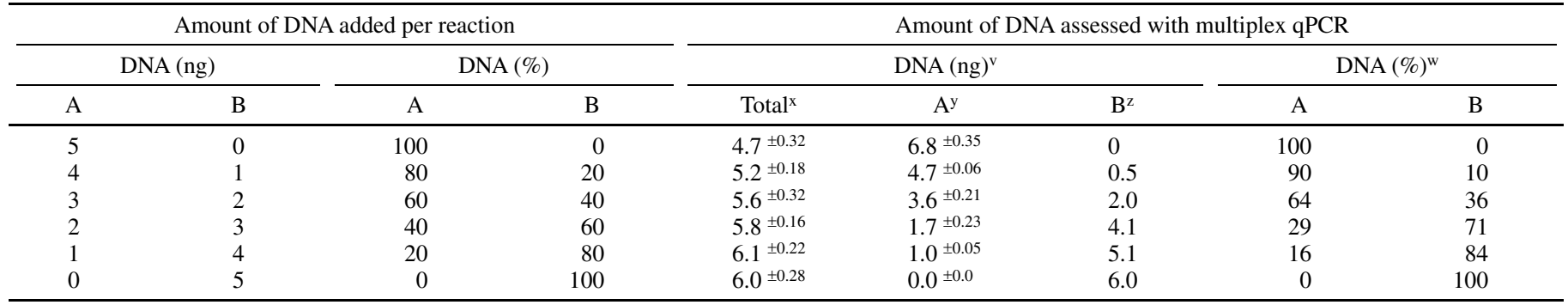

${ }^{v}$ Absolute quantity of DNA based on a standard curve. Value represents the mean of four replications; \pm represents one standard error of the mean.

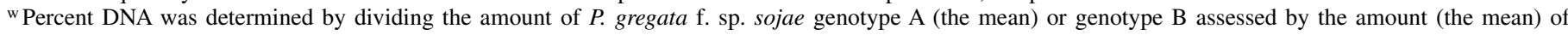
"Total" DNA detected and multiplying by 100 . A $100 \%$ value was recorded for samples $\geq 100 \%$.

x Total amount of $P$. gregata f. sp. sojae DNA detected with the general primer/probe set (10).

y Amount of genotype A DNA detected with the genotype A-specific primer/probe set.

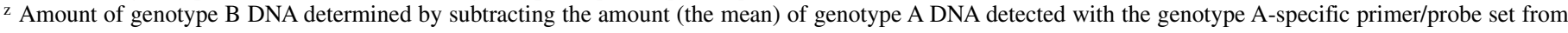
the Total amount (the mean) of P. gregata f. sp. sojae DNA detected with the general primer/probe set. When the amount of genotype A DNA detected was greater than the Total amount of DNA detected, a zero value was recorded for the amount of genotype B. 
grown in monoculture. These cultivars were selected based on prior information indicating that Jack supported a higher population of genotype B while Corsoy 79 supported a higher population of genotype A $(3,7,9)$. Cores were individually air dried and pulverized, and DNA was extracted as previously described. At growth stage R7 (beginning maturity), stems of Jack and Corsoy 79 were arbitrarily collected from within each of the four locations and air dried, and the lower 13 to $15 \mathrm{~cm}$ of stem was ground, first in a Wiley Mill (Thomas Scientific, Swedesboro, NJ) and then by a secondary grinding through a Cyclone Sample Mill (Udy Corp., Fort Collins, CO). DNA was extracted from $100 \mathrm{mg}$ of ground tissue with the FastDNA Spin Kit as previously described. The concentration of DNA in each sample was quantified with the NanoDrop ND-1000 spectrophotometer and the concentration of DNA adjusted as previously described. Each multiplex qPCR reaction contained $5 \mu \mathrm{l}$ of a $1 \mathrm{ng} / \mu \mathrm{l}$ concentration ( $5 \mathrm{ng}$ total) of soil-extracted DNA or $5 \mu \mathrm{l}$ of a $4 \mathrm{ng} / \mu \mathrm{l}$ concentration (20 ng total) of stem-extracted DNA. The quantity of DNA of $P$. gregata $\mathrm{f}$. sp. sojae genotype B was determined as previously described. The percentage of DNA belonging to either genotype was determined by dividing the amount of DNA detected (genotype A) or determined (genotype B) by the Total amount of DNA detected and multiplying by 100 . DNA quantities and percent values were analyzed as a randomized complete block design (RCBD) with PROC MIXED (SAS Institute, Cary, NC). Mean comparisons were obtained by using the LSMEANS and PDIFF options and letter separations were generated with the PSMIX612 macro (14). Comparisons of the means were conducted at $P \leq 0.05$.

The quantity of $P$. gregata f. sp. sojae in stems of cvs. Jack and Corsoy 79 was also determined by dilution plating onto a semiselective medium as previously described $(1,8,12)$. Colonies of $P$. gregata $\mathrm{f}$. $\mathrm{sp}$. sojae were arbitrarily selected from the dilution plates of each cultivar and transferred to quarter-strength potato dextrose agar (PDA) (25 g of peeled, sliced potato; $1.25 \mathrm{~g}$ of dextrose; $7.5 \mathrm{~g}$ of agar; and $500 \mathrm{ml}$ of deionized water). Fourteen isolates from Corsoy 79 and 17 isolates from Jack were subsequently transferred to full-strength PDA and incubated at room temperature for 2 weeks. Mycelium from each isolate was removed from the agar with a sterile scalpel and the DNA extracted with the FastDNA Spin Kit following the manufacturer's protocol. The genotype of each isolate was determined by gel electrophoresis following PCR with genotype-specific primers BSRIGS1 and BSRIGS2 as previously described (3). Colonies of P. gregata f. sp. sojae from dilution-plated soil could

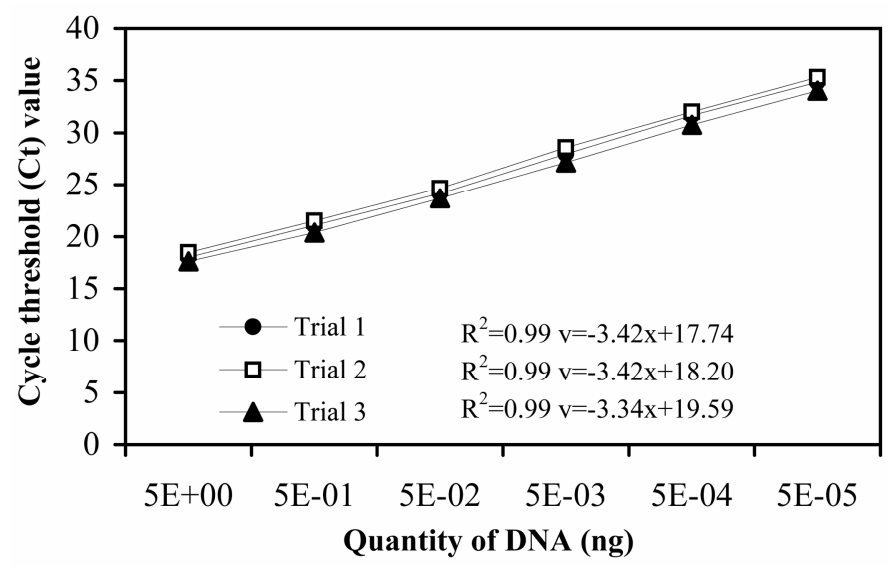

Fig. 1. Standard curves of a 10-fold serial dilution of Phialophora gregata $\mathrm{f}$. sp. sojae genotype A DNA with the genotype A-specific primer/probe set. Each point represents the mean of three replicates per trial. Standard error of the mean $\left(5.0\right.$ to $\left.5.0 \times 10^{-5}\right)$ was $0.12,0.09,0.04,0.09,0.08$, and 0.27 (trial 1$)$; $0.17,0.17,0.03,0.15,0.08$, and 0.21 (trial 2); and 0.10, 0.13, 0.30, 0.37, 0.06, and 0.03 (trial 3). not be sufficiently distinguished from other soil microbes, preventing the quantification or isolation of $P$. gregata $\mathrm{f}$. sp. sojae from soil samples. Spearman's rank-order correlations $(R)$ were calculated with PROC CORR to determine the association between the number of $P$. gregata $\mathrm{f}$. sp. sojae colonies from dilution plating and the results of qPCR.

\section{RESULTS}

Sensitivity and specificity of $\boldsymbol{P}$. gregata $\mathrm{f}$. sp. sojae genotype A-specific primers and probe. A nucleotide-nucleotide BLAST search using sequences for the $P$. gregata $\mathrm{f}$. sp. sojae genotype Aspecific primer/probe set and the 69-bp amplicon indicated sequence specificity to $P$. gregata $\mathrm{f}$. sp. sojae. Forward and reverse primers had $100 \%$ homology to genotypes A and B. The sequence for the genotype A-specific probe was $100 \%$ identical to genotype A with no homology to known sequences for $P$. gregata $\mathrm{f}$. sp. sojae genotype $\mathrm{B}$. The 69-bp amplicon generated by the genotype A-specific primer/probe set had $71 \%$ homology to the IGS sequence of genotype B. In addition, the sequences for the genotype A-specific probe and the 69-bp amplicon had $\leq 80$ and $28 \%$ homology, respectively, to other sequences in the NCBI database.

The genotype A-specific primer/probe set failed to amplify (cycle threshold $[\mathrm{Ct}]$ value $\geq 40$ ) 5 to $50 \mathrm{ng}$ of DNA from 36 fungi, oomycetes, and bacteria (Table 1) commonly associated with soybean or related to Phialophora spp., including $P$. gregata f. sp. sojae genotype B (data not shown). In addition, no amplification was detected following qPCR with DNA from noninfested soil. Slight amplification was detected (Ct values of 34 to 36 ) following qPCR with $50 \mathrm{ng}$ of DNA from a disease-free soybean plant. No amplification was detected when the concentration of soybean DNA was reduced to $45 \mathrm{ng}$ (data not shown).

The genotype A-specific primer/probe set repeatedly amplified $5.0 \mathrm{ng}$ (mean Ct of 18.0) to $5.0 \times 10^{-5} \mathrm{ng}$ (mean Ct of 34.7) of DNA from a pure culture isolate of genotype A (Fig. 1). Primer efficiency was 96 to $99 \%$. No amplification was detected following qPCR with serially diluted DNA from a pure culture isolate of genotype B. Amplification of DNA from genotype A was not affected by the presence of soybean or soil DNA (Fig. 2).

Detection of $P$. gregata f. sp. sojae and $P$. gregata f. sp. sojae genotype A with multiplex qPCR. A previously developed $P$. gregata f. sp. sojae general primer/probe set (10) was used in a multiplex assay with the genotype A-specific primer/probe set to simultaneously detect and quantify DNA of $P$. gregata f. sp. sojae

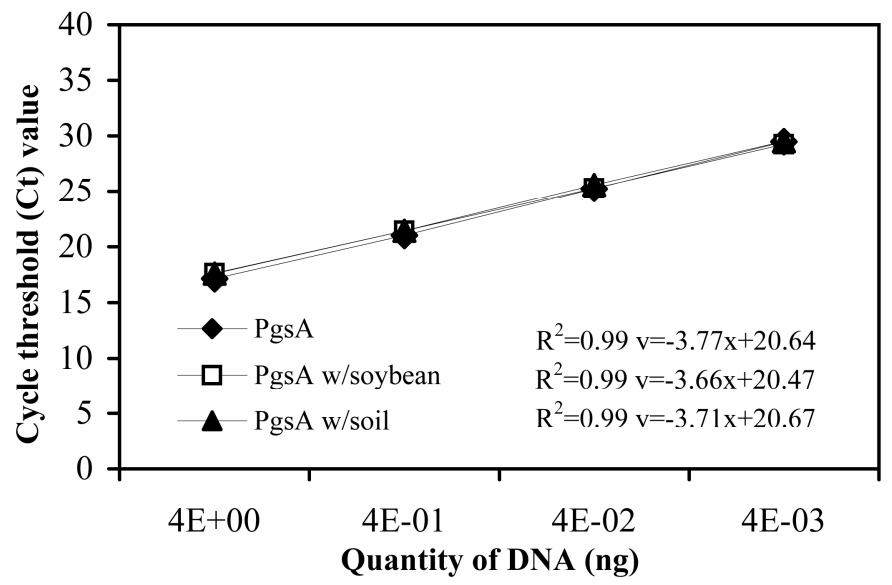

Fig. 2. Standard curves of a 10-fold serial dilution of Phialophora gregata f. sp. sojae genotype A (PgsA) DNA alone, with $10 \mathrm{ng}$ of soybean DNA, or $1 \mathrm{ng}$ of soil DNA with the genotype A-specific primer/probe set. Each point represents the mean of three replicates. Standard error of the mean $\left(4.0\right.$ to $\left.4.0 \times 10^{-4}\right)$ was $0.09,0.16,0.15$, and 0.28 (genotype A alone); 0.16, 0.04, 0.01, and 0.29 (genotype A with soybean); and $0.12,0.12,0.25$, and 0.20 (genotype A with soil). 
and $P$. gregata f. sp. sojae genotype A, respectively. $\mathrm{Ct}$ values and primer efficiencies for serial dilutions of genotype A DNA obtained from a singleplex assay were similar to those obtained in a multiplex assay, indicating that amplification was not affected by multiplexing (Figs. 1 and 3). As previously observed in singleplex reactions, the genotype A-specific primer/probe set failed to amplify DNA from genotype B (Fig. 3).

DNA of $P$. gregata f. sp. sojae genotype A was amplified from artificially infested soil with the multiplex qPCR assay. The $\mathrm{Ct}$ values obtained were 30.7 for the general primer/probe set and 31.4 for the genotype A-specific primer/probe set. DNA of $P$. gregata f. sp. sojae was also amplified from soybean cv. Corsoy 79 and accession PI567.157A inoculated with an isolate of either genotype A or B (Table 3). The genotype A-specific primer/probe set failed to amplify DNA from either soybean accession inoculated with an isolate of genotype B. In addition, both the general and genotype A-specific primer/probe sets failed to amplify DNA from mock-inoculated soybean plants.

Quantification of $\boldsymbol{P}$. gregata f. sp. sojae genotype B. DNA of $P$. gregata $\mathrm{f}$. sp. sojae genotype B was quantified by subtracting the quantity of genotype A DNA detected with the genotype Aspecific primer/probe set from the Total quantity of $P$. gregata $\mathrm{f}$. sp. sojae DNA detected with the general primer/probe set (Table 2). Quantification with the general primer/probe set tended to overestimate the quantity of $P$. gregata $\mathrm{f}$. sp. sojae DNA present as the concentration of DNA of genotype A decreased (Table 2). In contrast, quantification with the genotype A-specific primer/
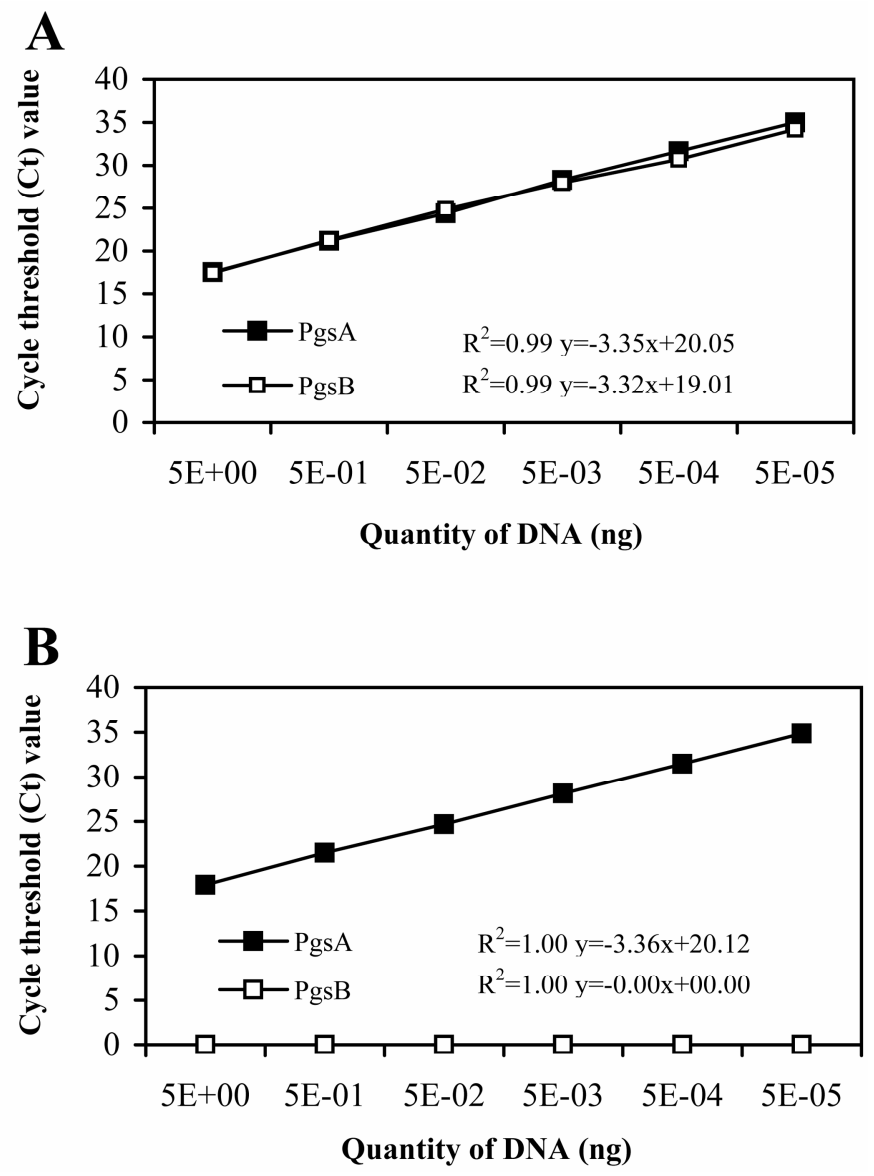

Fig. 3. Multiplex, quantitative polymerase chain reaction standard curves of a 10-fold serial dilution of Phialophora gregata f. sp. sojae genotype A (PgsA) or genotype B (PgsB) DNA. A, P. gregata f. sp. sojae general primer/probe set (10). B, Genotype A-specific primer/probe set. Each point represents the mean of three replicates. Standard error of the mean $\left(5.0\right.$ to $\left.5.0 \times 10^{-5}\right)$ was 0.15 , $0.03,0.03,0.10,0.18$, and 0.46 (genotype A with general primer/probe); 0.01 , $0.18,0.24,0.13,0.24$, and 0.39 (genotype B with general primer/probe); and $0.13,0.02,0.05,0.01,0.06$, and 0.05 (genotype A with specific primer/probe). probe set tended to overestimate the quantity of genotype A DNA present as the concentration of DNA of genotype A increased (Table 2). As a result, a slightly higher quantity of $P$. gregata f. sp. sojae genotype B DNA was detected than was truly present when the quantity of genotype A DNA was low (Table 2). However, based on either the quantity of DNA detected or the percentage of the total DNA determined, the above multiplex assay provides a way to estimate the amount of genotype B present in a sample (Table 2).

Quantification of $P$. gregata $\mathrm{f}$. sp. sojae genotypes A and B from naturally infested soil and field-grown plants. The multiplex qPCR assay reported here was used to determine the amount of genotype A and B DNA present in soybean stems and soil samples obtained from field sites monocultured to BSR-susceptible cv. Corsoy 79 or BSR-resistant cv. Jack. Both genotypes $\mathrm{A}$ and $\mathrm{B}$ were detected in soil samples regardless of cultivar. The amount of Total DNA, genotype A DNA, and genotype B DNA determined with multiplex qPCR was higher for Corsoy 79 than for Jack (Table 4). Based on the amount of DNA detected, differences between Corsoy 79 and Jack were significantly different for Total $(P=0.008)$ and genotype A DNA $(P=0.0002)$. Based on the percent Total DNA determined as either genotype A or $\mathrm{B}$, Corsoy 79 had significantly more $(P=0.0001)$ DNA of genotype A than Jack, which had significantly more $(P=0.0001)$ DNA of genotype B than Corsoy 79 (Table 4). Similar results were obtained for soybean stems, except that no DNA of genotype A was detected in stems of Jack (Table 4). Results obtained from soybean stems with dilution plating and standard PCR methods corresponded (Spearman's rank-order correlation: $R=0.72, P<$ $0.0001)$ to those results obtained with the multiplex qPCR assay (Tables 4 and 5).

\section{DISCUSSION}

The primer/probe set PgsAspF-PgsAspR-PgsAspPR was specific to $P$. gregata f. sp. sojae genotype A and failed to amplify DNA from $P$. gregata $\mathrm{f}$. sp. sojae genotype $\mathrm{B}$. In addition, the genotype A-specific primer/probe set did not amplify DNA from other soybean associated fungi, oomycetes, and bacteria, including Hymenula cerealis (syn. Cephalosporium gramineum), several species of Acremonium, and Gaeumannomyces graminis var. avenae. The slight amplification of $50 \mathrm{ng}$ of soybean DNA (Ct values of 34 to 36) was unexpected because no homology was identified between soybean and the sequences for the genotype Aspecific primer/probe set. Some qPCR assays establish limit-ofdetection cut-offs between cycles 34 and 36 (typical qPCR assays are 40 cycles) to account for reaction inefficiencies and consider a sample positive only when the $\mathrm{Ct}$ value is $<34$ or 36 (10). Another possible explanation for the slight amplification observed with soybean DNA could be colonization of the soybean plant from

TABLE 3. Detection of Phialophora gregata f. sp. sojae in greenhouse-grown soybean cv. Corsoy 79 and plant introduction (PI) 567.157A inoculated with either genotype A or B with a multiplex quantitative, real-time polymerase chain reaction ( $\mathrm{qPCR}$ ) assay

\begin{tabular}{lccc}
\hline & & \multicolumn{2}{c}{ qPCR Ct value $^{\mathrm{x}}$} \\
\cline { 3 - 4 } Soybean cultivar & Genotype & General $^{\mathrm{y}}$ & Genotype A-specific $^{\mathrm{z}}$ \\
\hline Corsoy 79 & $\mathrm{A}$ & 20.1 & 17.9 \\
& $\mathrm{~B}$ & 22.0 & $\mathrm{ND}$ \\
PI 567.157A & $\mathrm{A}$ & 25.6 & 23.5 \\
& $\mathrm{~B}$ & 22.6 & $\mathrm{ND}$ \\
\hline
\end{tabular}

${ }^{x}$ Cycle threshold $(\mathrm{Ct})$ is the cycle number at which fluorescence generated during the reaction crosses the threshold. The $\mathrm{Ct}$ value is inversely proportional to the quantity of DNA detected.

y $P$. gregata f. sp. sojae general primer/probe set (10), which amplifies both genotypes $\mathrm{A}$ and $\mathrm{B}$.

${ }^{z}$ Genotype A-specific primer/probe set, which only amplifies genotype A. ND = nondetectable; no DNA amplification detected. 
infected seed. In a preliminary experiment, DNA from soybean seed collected from field-grown plants tested positive for $P$. gregata f. sp. sojae with qPCR (Ct values of 32 to 37) (T. J. Hughes, unpublished). Whether amplification was the product of reaction inefficiencies or seed infection, no amplification was detected when the concentration of DNA was reduced to $45 \mathrm{ng}$. Also, no amplification was detected in $20 \mathrm{ng}$ of DNA from mockinoculated soybean plants, and the addition of $10 \mathrm{ng}$ of soybean DNA did not affect amplification of serially diluted $P$. gregata $\mathrm{f}$. sp. sojae genotype A DNA (Fig. 2). However, to forestall possible interference of host DNA in amplification of $P$. gregata $\mathrm{f}$. sp. sojae from field samples, the quantity of DNA extracted from field-grown plants used in each qPCR reaction did not exceed $20 \mathrm{ng}$.

Multiplexing the genotype A-specific primer/probe set with the primer/probe set of Malvick and Impulitti (10) allowed for simultaneous amplification of Total DNA and genotype A DNA from pure culture, artificially infested soil and inoculated soybean plants, and naturally infested soil and field-grown plants. Because $P$. gregata f. sp. sojae genotypes A and $\mathrm{B}$ are distinguished by variation in the length of the IGS region, and no DNA sequence has been indentified among isolates of genotype B that isn't found in isolates of genotype A (3), an individual primer/probe set could not be developed for genotype B. However, by subtracting the amount of DNA detected with the genotype A-specific primer/ probe set from the amount of DNA detected with the general primer/probe set (Total), we were able to estimate the quantity of DNA of genotype B present in each sample.

In the present study (Fig. 3) and the work by Malvick and Impullitti (10), the $P$. gregata f. sp. sojae general primer/probe set consistently and indiscriminately amplified DNA of both genotypes. In contrast, the genotype A-specific primer/probe set amplified DNA of genotype A only (Fig. 3). Although this was verified in the current study using only three isolates of each genotype, identical results have been obtained in subsequent experiments with 15 additional isolates of genotype B and 4 isolates of genotype A (5) (T. J. Hughes, unpublished). These data suggest that both primer/probe sets are applicable across populations of $P$. gregata f. sp. sojae. Although neither primer/probe set specifically detects genotype $B$, the presence of only genotype $\mathrm{B}$ in a sample may be ascertained when there is amplification with the general primer/probe but an absence of amplification with the genotype A-specific primer/probe.

Application of this multiplex assay to samples with known quantities of each genotype resulted in a greater amount of genotype A DNA detected than was actually present when the quantity of genotype B was lower than the quantity of genotype A. In contrast, more genotype B DNA was detected than actually present when the quantity of genotype A was lower than the quantity of genotype B (Table 2). For samples in which only genotype A was present, the amount of DNA detected with the genotype A-specific primer/probe set would be greater than the amount of Total DNA detected with the general primer/probe set. In these situations, the difference between the amount of genotype A DNA detected and the Total amount of DNA detected would result in a negative number. For these samples, it was assumed that the negative number signified an absence of DNA of genotype $\mathrm{B}$ and a zero value was recorded. Overall, these deviations from the actual amount of DNA present were minor and did not alter the interpretation of the results.

This multiplex qPCR assay provides an invaluable tool that allows for the simultaneous quantification and differentiation of $P$. gregata f. sp. sojae genotypes A and B. Although similar information can be obtained from dilution plating and the isolation and genotyping of each isolate with standard PCR and electrophoresis, the multiplex qPCR assay reported here is less time

TABLE 4. Quantity of DNA of Phialophora gregata f. sp. sojae genotypes A and B assessed in soil and stem samples collected from field locations monocultured to brown stem rot (BSR)-susceptible soybean cv. Corsoy 79 or BSR-resistant cultivar Jack with a multiplex quantitative, real-time polymerase chain reaction (qPCR) assay

\begin{tabular}{|c|c|c|c|c|c|c|c|c|}
\hline \multirow[b]{2}{*}{ Sample, cultivar } & \multicolumn{3}{|c|}{ DNA $(\mathrm{pg})^{\mathrm{v}}$} & \multicolumn{3}{|c|}{ DNA (ng) } & \multicolumn{2}{|c|}{ DNA $(\%)^{\mathrm{w}}$} \\
\hline & Total $^{\mathrm{x}}$ & $\mathrm{A}^{\mathrm{y}}$ & $\mathrm{B}^{\mathrm{z}}$ & Total $^{\mathrm{x}}$ & $\mathrm{A}^{\mathrm{y}}$ & $\mathrm{B}^{\mathrm{z}}$ & A & B \\
\hline \multicolumn{9}{|l|}{ Soil } \\
\hline Corsoy 79 & $1.39 \pm 0.17 \mathrm{a}$ & $0.48 \pm 0.11 \mathrm{a}$ & $0.92 \pm 0.19 \mathrm{a}$ & $\ldots$ & $\ldots$ & $\ldots$ & $38^{ \pm 7} \mathrm{a}$ & $62 \pm 7 b$ \\
\hline \multicolumn{9}{|l|}{ Plant } \\
\hline Corsoy 79 & $\ldots$ & $\ldots$ & $\ldots$ & $16.34 \pm 2.3 \mathrm{a}$ & $8.64 \pm 0.8 \mathrm{a}$ & $7.70 \pm 1.0 \mathrm{a}$ & $61 \pm 4 \mathrm{a}$ & $39^{ \pm 4} \mathrm{~b}$ \\
\hline Jack & $\ldots$ & $\ldots$ & $\ldots$ & $10.29 \pm 1.0 \mathrm{~b}$ & $0.00 \pm 0.0 \mathrm{~b}$ & $10.29 \pm 1.7 \mathrm{a}$ & $0 \pm 0 \mathrm{~b}$ & $100 \pm 0 \mathrm{a}$ \\
\hline
\end{tabular}

${ }^{v}$ Absolute quantity of DNA based on a standard curve. Value represents the mean of four replications; \pm represents one standard error of the mean.

wPercent DNA was determined by dividing the amount of $P$. gregata f. sp. sojae genotype A or B assessed by the amount of "Total" DNA detected and multiplying by 100 . A $100 \%$ value was recorded for samples $\geq 100 \%$. All calculations were made prior to data analysis; \pm represents one standard error of the mean.

${ }^{x}$ Total amount of $P$. gregata f. sp. sojae DNA detected with the $P$. gregata f. sp. sojae general primer/probe set (10). Means followed by different letters are significantly different at $P=0.05$.

y Amount of genotype A DNA detected with the P. gregata f. sp. sojae genotype A-specific primer/ probe set. Means followed by different letters are significantly different at $P=0.05$.

${ }^{\mathrm{z}}$ Amount of genotype B DNA determined by subtracting the amount (the mean) of genotype A DNA detected with the genotype A-specific primer/probe set from the Total amount (the mean) of $P$. gregata f. sp. sojae DNA detected with the general primer/probe set. When the amount of genotype A DNA detected was greater than the Total amount of DNA detected, a zero value was recorded for the amount of genotype B. All calculations were made prior to data analysis. Means followed by different letters are significantly different at $P=0.05$.

TABLE 5. CFU of Phialophora gregata f. sp. sojae and the number of isolates obtained belonging to genotypes A or B from dilution plating stem tissue of brown stem rot (BSR)-susceptible cv. Corsoy 79 and BSR-resistant cv. Jack

\begin{tabular}{|c|c|c|c|c|c|c|}
\hline \multirow[b]{2}{*}{ Soybean cultivar } & \multirow[b]{2}{*}{$\mathrm{CFU}^{\mathrm{y}}$} & \multicolumn{3}{|c|}{ Isolates of $P$. gregata f. sp. sojae ${ }^{Z}$} & \multicolumn{2}{|c|}{ Total isolates $(\%)$} \\
\hline & & Total no. & A & B & A & B \\
\hline Corsoy 79 & $8,500 \pm 4,839$ & 14 & 8 & 6 & 57 & 43 \\
\hline Jack & $3,800 \pm 1,416$ & 17 & 0 & 17 & 0 & 100 \\
\hline
\end{tabular}

y Value represents the mean of four replications; \pm represents one standard error of the mean.

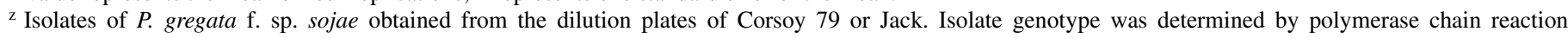
amplification of the intergenic spacer region of ribosomal DNA (3). 
consuming and labor intensive. In addition, this assay is more sensitive to low levels of colonization than dilution planting and is specific only to $P$. gregata $\mathrm{f}$. sp. sojae, which allows for the study of $P$. gregata f. sp. sojae populations in soil. Although they are a fundamental component of the disease cycle, little is known about soil populations of $P$. gregata $\mathrm{f}$. sp. sojae. Previous studies by Chen et al. (3), Malvick et al. (9), and Meng et al. (11) suggest that stem populations of $P$. gregata $\mathrm{f}$. sp. sojae are influenced by the genetics of the soybean cultivar. However, studies by Bachman and Nickell (2) and Tabor et al. (15) suggest that the interaction between $P$. gregata f. sp. sojae and its soybean host differs between the tissues of the root and stem. Following harvest, colonized root tissue remains in the field and may serve as a source of inoculum in addition to stem residue. In order to improve management of BSR, it is necessary to know if soybean roots influence $P$. gregata f. sp. sojae populations differently than stem tissue. With the development of this multiplex assay, we can begin to develop a better understanding of the host-pathogen interaction in both stem and root tissue. In addition, this assay can also be used to study survival of $P$. gregata $\mathrm{f}$. sp. sojae genotypes over time and efficacy of crop rotations, or to assess resistance in soybean breeding programs. This assay also demonstrates the possibility of using qPCR to quantify closely related species when limited sequence variability precludes the development of specific primers/probe sets for each species.

\section{ACKNOWLEDGMENTS}

This research was funded by a Hatch grant through the University of Wisconsin-Madison College of Agriculture and Life Sciences and a grant through the Wisconsin Soybean Marketing Board. We thank R. Reedy for his help in the initial stages of this project and C. Allen and J. Andrews for their assistance in the preparation of this manuscript.

\section{LITERATURE CITED}

1. Adee, E. A., Grau, C. R., and Oplinger E. S. 1997. Population dynamics of Phialophora gregata in soybean residue. Plant Dis. 81:199-203.
2. Bachman, M. S., and Nickell, C. D. 1999. Use of reciprocal grafting to study brown stem rot resistance in soybean. Phytopathology 89:59-63.

3. Chen, W., Grau, C. R., Adee, E. A., and Meng, X.-Q. 2000. A molecular marker identifying subspecific population of the soybean brown stem rot pathogen, Phialophora gregata. Phytopathology 90:875-883.

4. Harrington, T. C., Steimel, J., Workneh, F., and Yang, X. B. 2003. Characterization and distribution of two races of Phialophora gregata in the North-Central United States. Phytopathology 93:901-912.

5. Hughes, T. J. 2009. Phialophora gregata f. sp. sojae IGS-genotype B and the development of brown stem rot of soybean. Ph.D. thesis, University of Wisconsin-Madison, Madison.

6. Hughes, T. J., Chen, W., and Grau, C. R. 2002. Pathogenic characterization of genotype A and B of Phialophora gregata f. sp. sojae. Plant Dis. 86:729-735.

7. Hughes, T. J., Kurtzweil, N. C., Diers, B. W., and Grau, C. R. 2004 Resistance to brown stem rot in soybean germ plasm with resistance to the soybean cyst nematode. Plant Dis. 88:761-768.

8. Impullitti, A. E., and Grau, C. R. 2006. Population dynamics of Phialophora gregata in stem residue of a resistant and a susceptible soybean cultivar. Plant Dis. 90:759-764.

9. Malvick, D. K., Chen, W., Kurle, J. E., and Grau, C. R. 2003. Cultivar preference and genotype distribution of the brown stem rot pathogen Phialophora gregata in the Midwestern United States. Plant Dis. 87:1250-1254.

10. Malvick, D. K., and Impullitti, A. E. 2007. Detection and quantification of Phialophora gregata in soybean and soil samples with a quantitative, realtime PCR assay. Plant Dis. 91:736-742.

11. Meng, X.-Q., Grau, C. R., and Chen, W. 2005. Cultivar preference exhibited by two sympatric and genetically distinct populations of the soybean fungal pathogen Phialophora gregata f. sp. sojae. Plant Pathol. 54:180-188

12. Mengistu, A., Tachibana, H., and Grau, C. R. 1991. Selective medium for the isolation and enumeration of Phialophora gregata from soybean straw and soil. Plant Dis. 75:196-199.

13. Patzoldt, M. E., Grau, C. R., Stephens, P. A., Kurtzweil, N. C., Carlson, S. R., and Diers, B. W. 2005. Localization of a quantitative trait locus providing brown stem rot resistance in the soybean cultivar Bell. Crop Sci. 45:1241-1248.

14. Saxton, A. M. 1998. A macro for converting mean separation output to letter groupings in PROC MIXED. Pages 1243-1246 in: Proc. 23rd SAS Users Group Int. SAS Institute, Cary, NC.

15. Tabor, G. M., Tylka, G. L., Cianzio, S. C., and Bronson, C. R. 2003. Resistance to Phialophora gregata is expressed in the stems of resistant soybeans. Plant Dis. 87:970-976. 